\title{
Opposing Forces: \\ Distance and Proximity in Peter Brook's Mahabharata
}

\author{
Dominic Glynn
}

Jean Duvignaud noted that there was something incredibly odd about the idea of meeting up in a dark room to watch a group of people play out a text written several centuries ago. ${ }^{1}$ Yet, despite the fact that 'jouer les classiques [...] ne va pas de soi', ${ }^{2}$ every week in France and in Western Europe at least, there are new productions of plays by Shakespeare, Calderon, Corneille or Chekhov. Staging material taken from the annals of literary and theatre history requires the balancing of opposing forces, particularly since these curious cultural productions are deemed both to reflect - or rather to diffract ${ }^{3}$ - the thinking of a particular time period and place, and to present universal qualities, which allow them to be understood today. Thus, does one choose to present such a work as close to the audience (in modern dress, for instance) or as far-removed, distant? How does one create a delicate balance between telling the story and providing a novel interpretation? For, as Patrice Pavis explains in La Mise en scène contemporaine: origines, tendances, perspectives, 'mettre en scène, c'est [...] reconnaître la dramaturgie de l'œuvre et trouver les moyens scéniques à la fois de l'illustrer et accessoirement de la découvrir d'un œil nouveau.'4

Imaginative and profound (re)interpretations of canonical works address these issues head on. Since his move to Paris in 1970, director Peter Brook has provided many strong interpretations of keystone

1. Jean Duvignaud, Le Théâtre et après (Paris: Casterman, 1974), p. 56.

2. Bernard Dort, La Représentation émancipée (Arles: Actes Sud, 1988), p. 51.

3. Alain Viala argues that the mirror is an inappropriate metaphor to describe how literature and theatre practice interact with social discourse and events. More accurate is the metaphor of the prism, which 'diffracts'. See, for example, his Approches de la réception (Paris: PUF, 1993), p. 187.

4. Patrice Pavis, La Mise en scène contemporaine: origines, tendances, perspectives (Paris: Armand Colin, 2007), p. 25. 
works of dramatic and non-dramatic literature, chief among which, the Mahabharata, first presented at the 1985 Avignon festival. In this article, I wish to explore how Brook juggled with the opposing forces of universality and specificity in his production of a work taken from a distant past and described as 'Indian and universal'. ${ }^{5}$ I wish to do so via the conceit of the storyteller who (re)tells tales sourced from an ancient past and who is simultaneously both involved in the fiction and able to distance himself to provide commentary and analysis. The storyteller is a paradoxical figure who works to charm and entertain the audience - a sort of magician performing revels with spirits on his island - while at the same time making his mediating presence felt. He or she therefore operates in a shifting space between the fable and the audience, somewhat akin to the 'intervalle' Maurice Blanchot suggests that Bertolt Brecht creates in his theatre:

Brecht fera tout pour mettre un intervalle entre les éléments différents dont le théâtre est fait: intervalle entre l'auteur et la 'fable', entre le jeu et l'événement, entre l'acteur et le personnage, et surtout le plus grand intervalle entre l'acteur et le public, entre les deux moitiés du théâtre. ${ }^{6}$

It may seem strange to consider Brook's practice in relation to that of Brecht's given that the former does not believe in the political agency of theatre. As he argued in an interview in 2010, 'we don't do a play to tell societies anything', adding 'no play whatsoever in the whole of history, in all the countries of the world, has ever changed the policy of the world' ${ }^{7}$ Yet Brook is a pragmatic practitioner who in the course of his career has revisited the theories and methodologies of a number

5. The publicity material for the production frequently makes this point, as in the programme notes written by Brook for the English-language touring production. (See 4-COL-14 (25,1-11) BNF).

6. Maurice Blanchot, L'Entretien infini (Paris: Gallimard, 1969), p. 532.

7. Peter Brook (interview), 'Peter Brook at 84: Politics, philosophy and plays', Guardian online http://www.guardian.co.uk/stage/video/2010/feb/26/peter-brookpolitics [Accessed 12 June 2014]. 
of leading theatre-makers and thinkers from Artaud to Grotowski. ${ }^{8}$ The question to consider here is how Brook reconfigures Brecht's conception of epic theatre in order to provide a vitalised experience.

In order to do so, it is necessary to look at three different components of Brook's Mahabharata: the text, the actors' performances and the venues. ${ }^{9}$ I will begin by considering the attempts to simplify the material in order to render it more accessible. Secondly, I shall consider some of the framing and distancing devices at play in both in the texts and in performance. Brecht's estrangement effect will provide the theoretical basis for what shall be the main part of my article. Finally, I shall study how the performance venues provide a transitory space necessary to calibrate ancient narratives.

\section{Granting Access}

Jean-Claude Carrière was responsible for writing the play-text for Peter Brook's production of the Mahabharata. Given the complexity of the source material and French audiences' lack of familiarity with the Indian epic, it was necessary for him to simplify it in order to render it accessible. ${ }^{10}$ There is a complex social structure and moral reflection underpinning the Sanskrit Mahabharata. ${ }^{11}$ Yet much of the Hindu philosophical content was erased in Carrière's adaptation. ${ }^{12}$ Such

8. Brook worked with Charles Marowitz to create a 'Theatre of Cruelty' season at the RSC in 1964, while the cast of US undertook workshops with Grotowski in 1967.

9. The terms used by Richard Schechner, 'script, theatre and performance', in Performance Theory (Abingdon, Oxon and New York: Routledge, 1988) are somewhat equivalent, but add unnecessary confusion.

10. A number of dedicated scholars have sought to translate the poem into French, the first being Hippolyte Fauche, whose death prevented the work from being completed. A translation by Gilles Schaufelberger and Guy Vincent published by the Presses de l'Université de Laval is currently in progress. So far, four volumes have been published.

11. As Max Weber noted in Hindouisme et bouddhisme, trans. by Isabelle Kalinowski (Paris: Flammarion, 2001,) p. 284, the text is a moral treatise heavily reliant on example. Moreover, the social structure is itself structured by an even more complex cosmic structure, as Charles Malamoud explains in Cuire le monde: rite et pensée dans l'Inde ancienne (Paris: La Découverte, 1989), p. 198.

12. The only term to survive was that of dharma, which can be defined as 'une puissance 
erosion of specificity is part of the reason why Rustom Bharucha branded Brook's production as cultural tourism in line with the worst excesses of the British Raj. ${ }^{13}$ When considering theatre practices that seek to set up a dialogue between cultures, the question of whether globalisation has been favourable to international cultural exchanges and the mixing of cultures or whether it has been the illustration of economic imperialism accompanied by cultural hegemony, is inescapable, ${ }^{14}$ (although, as Patrice Pavis argues in Le Théâtre au croisement des cultures, such practices as Brook's may wish to ignore it). ${ }^{15}$

In addition to the lack of familiarity with the epic, another major issue was the length of the material. To give an order of magnitude, the Sanskrit text is roughly equivalent to fifteen times the length of the Christian Bible and eight times the combined length of the Iliad and the Odyssey. In Notes on Travels in India with Peter Brook, Carrière explains the anguish he felt whilst working on the script, questioning how he might include 'the origins, the births, the childhood, the tournament, marriage, different fights, Krishna's entrance on stage' without simply 'speed[ing] up the rhythm and let[ting] everything pass like a film clip — which would be a real betrayal'. ${ }^{16}$ Giving a sense of coherence and simplicity that is not apparent in the source materials, Carrière chose to focus on the core narrative, which concerns a family conflict between two sets of cousins. In Tous en scène, he justifies this choice by explaining that while the Mahabharata represents a sort of compendium of Indian traditions, it is above all the story of a devastating

surnaturelle, divine, sacrée, dont le rôle est de fournir une norme, un modèle'. (Jean Varenne, Dictionnaire de l'hindouisme (Paris: Éditions du Rocher, 2002), p. 130).

13. See notably the arguments raised in Theatre and the World: Performance and the Politics of Culture (London and New York: Routledge, 1993).

14. Translatio: le marché de la traduction en France à l'heure de la mondialisation, ed. by Gisèle Sapiro (Paris: CNRS, 2008), p. 7.

15. Patrice Pavis, Le Théâtre au croisement des cultures (Paris: Corti, 1990), p. 123.

16. Jean-Claude Carrière, In Search of the Mahabharata: Notes on Travels in India with Peter Brook, 1982, 1985, trans. by Aruna Vasudev (Chennai: Macmillan, 2001), p. 111. The fact that he had to cut so much material motivated him to work on a longer prose text published after the production cycle had finished. See Jean-Claude Carrière, Le Mahabharata (Paris: Belfond, 1989). 
family conflict that places the fate of the universe at stake. ${ }^{17}$ Sections and sub-sections that diverted from the family plot were thus cut out. This was notably the case with 'The Book of Bhishma', which reflects on the duties of a warrior-king and which, according to Carrière, depicts 'a society that is completely foreign even to contemporary India'. ${ }^{18}$

Moreover, he chose to include the character of Vyasa, the mythical composer of the poem, in his adaptation. ${ }^{19}$ Vyasa is seen narrating his poem to a young boy and the elephant-headed god Ganesha, a self-appointed scribe. In so doing, Carrière signalled the text's prior existence as an oral narrative and highlighted the extent to which stories are mediated and transformed in relation to their projected audiences. ${ }^{20}$ In production, the audience saw themselves represented in the figures of Ganesha and the boy: they listened to and watched a transposed version of themselves listening and watching. The presence of a narrator-storyteller character provided an interface between the fiction and the audience. As such, Vyasa's function was not dissimilar to that of a chorus in Greek tragedy, whose role it is to comment on the action, as Roland Barthes reminds us. ${ }^{21}$ Carrière saw the relevance the figure

17. Jean-Claude Carrière, Tous en scène (Paris: Odile Jacob, 2007), p. 118.

18. Quoted in Georges Banu et al, 'Talking with the Playwright, the Musician, the Designer', TDR, 30.1 (1986), 72-81, (p. 74). The Bhishmaparvan contains the standalone passage, the Bhagavad Gita, which in the Brook and Carrière version is reduced to a few lines.

19. 'Tradition involves Vyasa in many literary works, primarily as an arranger of the four Vedas [...] and author of the epic Mahabharata', explains Paramahansa Yogananda in God Talks with Arjuna: The Bhagavad Gita (LA: Self-Realization Fellowship, 1995), p. xx. However, the hypothesis of a single-authored piece is impossible given the length of material, and the stylistic inconsistencies. Hegel's presumption, expressed in Esthétique IV (trans. by S. Jankélévitch (Paris: Flammarion, 1979,) p. 106, that epic poetry is necessarily written by a single author is thus completely misguided.

20. Moreover in Sanskrit, indirect address is not a known stylistic feature, hence the reliance on characters re-telling events. See Jean Renou and Jean Filliozat, L'Inde classique I: Manuel des études indiennes (Paris: Librairie d'Amérique et d'Orient, 1985), p. 400. For James Hegarty, 'the Mahabharata is obsessively self-conscious about the place and time where stories are told and about who tells a given story to whom'. See his Religion, Narrative and Public Imagination in South Asia (London and New York: Routledge, 2012), p. 62.

21. Barthes described the chorus in Greek tragedy as 'le commentaire par excellence'. Roland Barthes, Sur Racine (Paris: Seuil, 1963), p. 44. 
of the storyteller in Brook's Mahabharata as testament to its origins in India. Indeed, he claimed that 'the storyteller is an essential person in Indian society, as much as the warrior or the baker. They understand perfectly that no society can survive if its own myths are not told to it'. ${ }^{22}$ On one level, therefore, the figure of the storyteller in Brook's Mahabharata functions as a device that allows the transposition of a non-dramatic text to the stage. More than that though, the storyteller represents a channel through which the great mythological stories of the past can be accessed. ${ }^{23}$

\section{Creating Distance}

The presence of a storyteller character creates an interface between the audience and the 'fable'. As a self-referential device, it highlights the idea that tales are shaped by their tellers. Indeed, the creation process is represented directly at several points when Vyasa directly intervenes in the story. He is required for instance to make love to two princesses so that they may have children. The two sons conceived by the princesses will father the rival clans of the Kauravas and the Pandavas. Quite literally, Vyasa becomes the life-giving force in this instance, as he is for the whole poem figuratively. As Carrière notes:

Splendide liberté du jeu de l'écriture: l'auteur doit faire l'amour à ses personnages, sinon son œuvre est en danger. Sans cette intervention, au demeurant peu désagréable (au moins pour l'ascète inspiré), le plus grand poème du monde tournerait court

22. Banu et al, 'Talking with the Playwright', p. 76.

23. Brook has been linked with the figure of the storyteller magician since his move to Paris. The review of Le Conférence des oiseaux which appeared in Le Matin, highlights his powers as a 'raconteur', a storyteller: 'Peter Brook est un magicien. Dans les ruines du cloître des Carmes, il nous raconte une histoire persane' (Anne Surgers, “"La conférence des oiseaux" de Peter Brook', Le Matin, 17 juillet 1979). p. 12. The magical qualities of the storyteller are reflected in his power to conjure up images or characters from the simplest of elements. Hence, Brook's storyteller-actor only needs a fan to suggest a peacock or a white veil to signify a heron. 
et s'arrêterait là. ${ }^{24}$

Vyasa's copulation with his characters acts as a metaphor of the act of creation. At other points, Vyasa takes on more of a repressive role, blocking events, editing them out of the text, as when he intervenes to prevent two Kauravas from killing the Pandavas:

VYASA Écarte ton arme, Dushassana! Obéis-moi!

Dushassana regarde Duryodhana, qui lui indique d'obéir, et lâche Yudishthira.

VYASA Aucun crime ne doit corrompre ce poème. ${ }^{25}$

And at yet another moment, Vyasa appears unsure of the direction to take, which leads the young boy to wonder whether he is in fact the author of the poem: 'Par moments tu hésites. On dirait même que tu ne sais plus rien. ${ }^{26}$ While Vyasa's creative and editorial role is evident therefore from the text, it is also clear that his role corresponds more precisely to the description Paul Ricœur provides of a narrator:

Le narrateur peut marcher au pas de ses personnages, mettant son présent de narration en coïncidence avec le sien, et acceptant ainsi ses limites et son ignorance; il peut au contraire se mouvoir en avant et en arrière, considérer le présent du point de vue des anticipations d'un passé remémoré ou comme le souvenir révolu

24. Carrière, Tous en scène, p. 118.

25. Carrière, Le Mahabharata, p. 183.

26. Carrière, Le Mahabharata, p. 107. This could be compared to Brook's approach as a director, which seeks to explore rather than follow a set path. 'Nothing is written down', indeed, or nothing is fixed. Brook evokes the issues of hesitation, questioning and doubt in the process of theatre-making in The Empty Space when he writes: 'In a sense the director is always an impostor, a guide at night who does not know the territory, and yet has no choice - he must guide, learning the route as he goes' (Peter Brook, The Empty Space (London: Penguin, 2008 [1968]), p. 44). In this regard, Brook's method can be seen to owe a great deal to Brecht's 'scientific approach, in which the director works most productively by asking questions rather than supplying the answers', as Michael Patterson argues. See Michael Patterson, 'Brecht's legacy', The Cambridge Companion to Brecht (Cambridge: Cambridge University Press, 1994), p. 282. 
d'un futur anticipé, etc. ${ }^{27}$

This time-travelling aspect of the narrator has been a key aspect throughout Peter Brook's theatre work with the Centre International de Création Théâtrale in Paris. In Les Iks (1975), an actor takes the stage to explain: 'Nous allons essayer ce soir de vous raconter une histoire vraie, l'histoire de la tribu des Iks. ${ }^{28}$ In the next line the actor explains the history of the Iks before noting that 'dix-huit ans plus tard, un ethnologue anglais, Colin Turnbull, alla les observer'. In La Conférence des oiseaux, the character of the hoopoe also weaves in and out the narrated past and performed present, as is illustrated in the following:

HUPPE Un jour tous les oiseaux du monde, ceux qui sont connus et ceux qui sont inconnus, se réunirent en une grande conférence.

Les oiseaux se rassemblent pour la conférence.

HUPPEQuand ils furent réunis, la Huppe, toute émue et pleine d'espérance, arriva et se plaça au milieu d'eux. ${ }^{29}$

The hoopoe introduces the performance as a storyteller, by using the phrase 'un jour', typical of the storytelling genre. Secondly, she is able to make the other characters appear through mere suggestion. As soon as she mentions that the birds met together, they arrive on stage. Finally, the hoopoe is both involved and set apart from the narrative that she develops. She is involved, since she is described as a character, and set apart since it is she who provides this description.

Such a relationship with the past and the present is close to that which is characteristic of Brecht's approach as described by Bernard Dort, whereby 'il s'agit de dire à la fois le présent et le passé - ce qui devrait conduire le spectateur à projeter - c'est-à-dire à désirer -

27. Paul Ricœur, Temps et récit, 3 vols (Paris: Seuil, 1984), II, p. 179.

28. Colin Higgins and Denis Cannan, Les Iks, trans. by Jean-Claude Carrière, (Paris: C.I.C.T., 1975), p. 13.

29. Carrière, La Conférence des oiseaux (Paris: Albin Michel, 2008) p. 15. 
le futur. Ici le présent n'est intensifié que pour être inclus dans une narration du passé'. ${ }^{30}$ Certainly the narration of events rather than their enactment is a key element of Bertolt Brecht's epic theatre as he defines it. ${ }^{31}$ This emphasis on narration rather than enactment is precisely what we witness in the Mahabharata at key moments. One such moment is when a night demon recounts her liaison with one of the Pandavas:

HIDIMBI Alors, transfigurée par la joie, Hidimbi devint une femme d'une beauté presque incroyable. Elle saisit Bhima, elle l'emporta dans les airs et partout, sur les sommets des montagnes, sur les plages bleues, dans les repaires secrets des gazelles, au bord des lacs lointains, partout elle lui fit l'amour.

BHIMA Ils eurent un fils?

HIDIMBI Un fils énorme, qui s'appelle Ghatokatcha. Le voici. ${ }^{32}$

In recounting their liaison, Hidimbi speaks to her lover as if he is a stranger. He in turn seems unaware of their history together. The enchanted locations described by Hidimbi belong to a folkloric landscape to which Bhima only has access through her, or rather, through her descriptions. Both speak in the third person singular as if speaking about someone else. Another key moment of the production at which narration is prioritised is when Krishna narrates the dialogue he has with Arjuna in the celebrated episode of the Bhagavad Gita.

In performance, the narration of an episode can help to open up a space between actor and character. Jean-Claude Carrière remarks how actors are encouraged to distance themselves from the characters they played. Describing Brook's method, he notes that, 'il dit fréquemment aux acteurs avec lesquels il travaille qu'ils doivent être, aussi, "les conteurs de leurs propres personnages"'. He goes on to note of the actor:

30. Dort, La Représentation émancipée, p. 46.

31. Bertolt Brecht, 'Le théâtre épique' in Écrits sur le théâtre, coll. de la Pléiade (Paris: Gallimard, 2000), p. 215.

32. Carrière, Le Mahabharata, p. 179. 
Il est entièrement engagé dans son jeu, mais il peut se retirer à chaque instant, contempler de loin son personnage, le regarder jouer, le désapprouver et même se moquer subtilement de lui, en prenant le public à témoin de sa balourdise. ${ }^{33}$

David Williams analyses the temporary rift that occurs between actor and character as 'furnishing him/her [the actor] with the objectivity, lucidity and compassion of a narratorial commentator or puppeteer' ${ }^{34}$ Williams sees Brook's interest in the storyteller as stemming from a desire to emphasise the simplicity of the performance and the delivery of the text, which 'retain the actor's capacity for transformability and psycho-physical empathy, and at the same time remain unencumbered by the superficial trappings of naturalistic impersonation'.${ }^{35}$ It is striking how these moments in the production resemble very closely an aspect of Helene Weigel's performance in Brecht's Die Mutter as described by Brecht himelf. Writing about how she spoke, Brecht indicated:

The sentences are spoken as if they were in the third person, and so she not only refrained from pretending in fact to be or to claim to be Vassova, and in fact to be speaking those sentences, but actually prevented the spectator from transferring himself to a particular room, as habit or indifference might demand, and imagining himself to be the invisible eye-witness and eavesdropper of a unique intimate occasion. ${ }^{36}$

Brook's actors thus reworked a key aspect of Brecht's directing practice in their performances of the Mahabharata, namely the distancing or estrangement effect. Just as Vyasa is the puppeteer for the overall

33. Carrière, Tous en scène, p. 262.

34. David Williams, 'The Great Poem of the World: a Descriptive Analysis', in Peter Brook and the Mahabharata: Critical Perspectives, ed. by David Williams (London and New York: Routledge, 1991), pp. 117-191 (p. 189).

35. David Williams, 'Theatre of Innocence and Experience: Peter Brook's International Centre. An Introduction', in Peter Brook and the Mahabharata, pp. 3-28 (p. 23).

36. Quoted in John Willett, The Theatre of Bertolt Brecht: A Study from Eight Aspects (London: Methuen, 1967), p. 174. 
narrative of the Mahabharata, jumping in and out of the story, aware of his own function in the overall hierarchy, the actor can step out of role to describe the actions of his character from a seemingly more objective vantage point.

Another feature of Brook's production was that the differences between the performers' backgrounds were exploited in order to create a mix of influences and traditions. This is what David Bradby refers to as a 'découpage':

Brook refuse l'unité stylistique au profit d'un 'découpage' qui doit sa fluidité et sa rapidité aux principes du découpage et montage cinématographiques. En même temps, il affranchit les acteurs, les encourage à développer leurs personnages en utilisant les techniques apprises dans leurs traditions natales, qu'elles soient européennes ou africaines, japonaises ou indiennes. ${ }^{37}$

The fact that Brook generally uses actors who have prior training creates disparities in the different acting styles. Some critics were struck by the 'radical' nature of the performance, ${ }^{38}$ while others despaired at the 'polyglot nature of the company', which in their view 'militate[d] against conviction and even comprehension' of the piece. ${ }^{39}$ For some, the 'intentional hotchpotch of diverse accents' contributed to creating a lack of 'theatrical coherence' evident in other aspects of the stage production, ${ }^{40}$ while for others, "coherence and unity here stem[med] from heterogeneity'. ${ }^{41}$ Vijay Mishra makes a noteworthy contribution to the argument in pointing out that the polyphonic nature of the production corresponded exactly to the performances that would take place in the home of the Mahabharata in India: 'The multiplicity of voices adds

37. David Bradby, Le Théâtre en France de 1968 (Paris: Honoré Champion, 2007), p. 469. 38. James Roose-Evans, Experimental Theatre from Stansilavsky to Peter Brook (London: Routledge, 1996), p. 193.

39. Francis King, 'Hindu Hijack', Sunday Telegraph, 24 April 1988. p. 19

40. Gautam Dasgupta, 'The Mahabharata: Peter Brook's Orientalism', Performing Arts Journal, 10.3 (1987) p. 15.

41. Williams, 'The Great Poem of the World', p. 191. 
both a new Mahabharata text to the canon, as well as extending the 'sounds' and 'voices' which make up any open-air theatre in India' ${ }^{42}$ Be that as it may, one could also argue that this emphasis on multiplicity and polyphony is also linked to Brecht's practice as he endeavours to work against the creation of too great a harmony, which would give the illusion of a natural world. ${ }^{43}$

Brook's work with the C.I.C.T., and most notably on the Mahabharata, sought to create new conditions via an extended performance time that lasted nine hours. It was possible to view the production either on three different evenings or in a single performance. The single performance offerings in many of the venues took place at night. The experience would have of course been remarkably different in each case. With night performances at Avignon, the cyclical functions of the body, which include sleep, were being consciously modified, since the spectators were expected to stay awake throughout. This is precisely what irritated the reviewer Charles Osborne who felt that: 'Human biorhythms being beyond the control of Peter Brook, his audience during the final lap was not at its most responsive'. ${ }^{44}$ Brook, however, was aware of the problems caused by a nightlong performance. He explained to Richard Schechner that ideally the performance would run between midday and midnight, as the company was able to do for an invited audience of friends, but that the all-night performance marathon was possible at Avignon because people were on holiday. ${ }^{45}$ Indeed, people took time out of their normal routines to view the performances, thus embarking on a long voyage.

Criticism of the length of the production was not limited to Avignon. Leonard Pronko, for instance, commenting on the Los Angeles

42. Vijay Mishra, 'The Great Indian Epic and Peter Brook', in Peter Brook and the Mahabharata, ed. by Williams, pp. 195-205, (p. 203).

43. See Brecht, 'L'Architecture de scène', in Écrits sur le théâtre, p. 751.

44. Charles Osborne, 'Doubts about the guru', Daily Telegraph, 21 March 1988, p. 14.

45. Richard Schechener et al, 'Talking with Peter Brook', Drama Review, 30.1 (1985), p. 60. At a previous festival, Brook indicated that he was particularly impressed by just how 'disponible' members of the audience were at Avignon. 'Peter Brook au festival d' Avignon', Samedi et demi, Antenne 2, 28 July 1979: http://www.ina.fr/video/CAB7901166701/peterbrook-au-festival-d-avignon-video.html [accessed 15 June 2014] 
production, notes that it is one of the longest plays in the Western world, and asks 'did it have to be quite this long?' 46 It is not surprising that the metaphor of the marathon is frequently used to describe the theatre experience provided in this production. For instance, the title of Jack Tinker's review for The Daily Mail is 'Marathon Winners' and Eric Shorter's less complimentary review for the Daily Telegraph also describes the event as a marathon. ${ }^{47}$ More favourably, Kent Devereaux, who attended the performance at the Brooklyn Academy of Music, noted how the 'marathon' presentation of the Mahabharata differed from traditional Western performances. As he put it: 'Audiences attending these performances, and especially the Halloween all-night performance, were treated to a journey of gargantuan proportions befitting the epic tale being told'. Devereaux also pointed out that the audiences were particularly receptive to this experience, displaying 'intensity and tenacity that I have rarely witnessed either in the Western theatre or in Asia', ${ }^{48}$

\section{Shifting Space}

The Jeema-el Fna Square in Marrakech has been inscribed on the UNESCO Intangible Cultural Heritage list since 2008. A number of diverse trades are plied in this square - fortune telling and dental care, for instance - and it is host to performances given by storytellers. Regarding the latter, the identification description provided by UNESCO states that 'they continue to combine speech and gesture to teach, entertain and charm the audience. Adapting their art to contemporary contexts, they now improvise on an outline of an ancient text, making their recital accessible to a wider audience'. ${ }^{49}$ Such a description highlights the idea

46. Leonard Pronko, 'Los Angeles Festival: Peter Brook's "The Mahabharata"', Asian Theatre Journal, 5.2 (1988), 220-24, (p. 220).

47. Shorter, 'A Passage from India', p. 14.

48. Kent Devereaux, 'Peter Brook's production of the Mahabharata at the Brooklyn Academy of Music', Asian Theatre Journal, 5.2, (1988), 225-32, (p. 228).

49. UNESCO http://www.unesco.org/culture/ich/RL/00014 [accessed 12 June 2014]. 
that storytelling represents a form of theatre reduced to its core value of exchange between a performer and audience, but also that the practice is anchored in space, both literal and metaphorical. Semioticians have highlighted the importance of studying how the very fabrics of theatre buildings, their organisation and spatial layout condition one's reading of a performance. To quote Marvin Carlson: 'The entire theatre, its audience arrangements, its other public spaces, its physical appearance, even its location within a city, are all important elements of a process by which an audience makes meaning of its experience. ${ }^{50}$ In other words, the venue and performance conditions provide the anchor with which to read images and texts presented on stage. They shape the discourse of a production.

The importance of space and, more specifically, ruinous space, is a key element of Brook's work. With regard to the venues chosen to stage Peter Brook's Mahabharata, they have something in common with Alcandre's grotto in Corneille's L'Illusion comique: they are hollowed out, de-cluttered spaces. Ever since his seminal theoretical work, The Empty Space, people have associated Brook with the concept of the void. ${ }^{51}$ For David Williams, the Bouffes du Nord, where Brook's company has been resident since the seventies, represents an 'espace trouvé [which] is above all a place marked by life, a silent witness to time', ${ }^{52}$ as the layers of paint, varnishing and furnishings have been stripped away. The critics who watched Timon d'Athènes, Brook's first production to be staged there, described a wounded space. Thus, L'Humanité speaks of 'les cicatrices blanches du plâtre', ${ }^{3}$ and the Herald Tribune jokes that the space 'looks as if it has been used for artillery practice and then been in an earthquake' ${ }^{54}$ For Colette Godard in Le Monde, the removal of a

50. Marvin Carlson, Places of Performance: the Semiotics of Theatre Architecture (New York: New York University Press, 1989), p. 2.

51. Jean-Guy Lecat, the technical manager for the Mahabharata, once wryly noted: 'Peter Brook says that all he needs is a simple empty space, but [I am] the one that has to build it'. Quoted in Michael Scott, 'Brook no quarry', Theatre Ireland, 11 (1985), 11-12, (p. 11).

52. Williams, 'An Introduction', p. 9

53. 'De l'or au désert, "Timon d'Athènes" de Shakespeare aux Bouffes du Nord', L'Humanité, 24 octobre 1974.

54. 'Peter Brook's latest — an obstacle course', International Herald Tribune, 25 October 
key component of theatre architecture, the stage, left 'a gouffre'. ${ }^{55}$ This absence implied a reorganisation of the actor-to-audience dynamics, as the performers were not separated from the auditorium. Rather a transitory space for communication was opened up.

Arguably, Georges Banu provides the most adequate reading of the politics of the Bouffes du Nord as a space, by recalling Antoine Vitez's classification of spaces:

Antoine Vitez classe les espaces théâtraux en deux catégories: l'abri, le lieu qui reçoit le théâtre sans être conçu à l'origine pour ce but, et l'édifice, le lieu consacré au théâtre et invalide en dehors de cette fonction. Par une belle alliance Brook parvient à les réunir dans les Bouffes du Nord où l'édifice s'apparente à l'abri. ${ }^{56}$

A similar duality might be applied to the space that best came to embody the Mahabharata. When Brook was invited to premiere the production at the 1985 festival Avignon festival, he eschewed the performance spaces in the medieval city, preferring instead to present the work at the Carrière Callet in Boulbon. He claimed that Avignon signified 'Popes, wine, good food, medieval charm', to most of its visitors. ${ }^{57}$ The quarry, however, offered a shell-like space, hewn out of the rock and freed from the discourse of medieval Catholicism prevalent in the architecture of the city. It also provided an escape from the frenzy of the city where theatre tourists move from show to show. ${ }^{58}$ The journey to the quarry by bus or by ferry down the river 'in style ${ }^{59}$ provided a transitory moment.

\footnotetext{
1974, p. 8
}

55. Colette Godard, ““ Timon d'Athènes” par Peter Brook’, Le Monde, 22 October, 1974, p. 16

56. Banu, Peter Brook, p. 33.

57. Brook quoted in Schechner et al, 'Talking with Peter Brook', p. 60.

58. It also provided an escape to nature, Brook claimed in a TV interview. See above, n.47, 'Peter Brook au Festival d'Avignon'.

59. Scott, 'Brook no quarry', p. 11. 


\title{
A Secular Ceremony
}

Describing the Bouffes du Nord, Michael Rattcliffe remarks that it 'is rather secretive and enclosing, like a baroque chapel or mosque'. ${ }^{60}$ The description of the venue resembling a religious edifice is supported by Patrice Pavis's definition of 'ritual' in his Dictionnaire du théâtre, in which he notes a return to a form of ceremony in modern theatre practice:

\begin{abstract}
Tout indique que le théâtre, après s'être à peine dégagé du rite et de la cérémonie, recherche désespérément à y revenir, comme si cette matrice d'un théâtre sacré [...] était pour lui sa seule chance de survie, au contact des arts de masse industrialisés et au sein de la tribu électronique. ${ }^{61}$
\end{abstract}

In an article written in 1968 entitled 'Le ciel et la merde', Brook provided a similar reading of the situation to Pavis, explaining that 'si les termes: 'Magie'... 'Cérémonie'... s'appliquent au théâtre contemporain, ce n'est pas l'effet d'un hasard. Dans notre société actuelle, le besoin d'une expérience collective existe' ${ }^{62}$ Declan Donnellan once stated that he expected theatre to undergo a revival in the virtual age, as people feel the need for real human contact. ${ }^{63}$ Such a comment derives more from personal fancy than concrete evidence. Yet it does point to a perceived need among those who make theatre for people to assemble and watch tales about 'kings and queens, liars and lovers: all kinds of real human beings living all the real human emotions' as Jerry Prokosch says in Jean-Luc Godard's Le Mépris. ${ }^{64}$

Brook claimed in The Empty Space that in the theatre, through the act of rendering present an act from the past, 'yesterday's action [...]

60. Michael Ratcliffe, 'Nice and Scary', The Observer, 1 November 1987, p. 23.

61. Patrice Pavis, Le Dictionnaire du théâtre (Paris: Editions Sociales, 1987), pp. 339-40.

62. Peter Brook, 'Le ciel et la merde', Théâtre, 1 (1968), p. 16.

63. Declan Donnellan, Post-show discussion of Andromaque, at which this author was present, in the Oxford Playhouse, 11 March 2009.

64. Jean-Luc Godard, Le Mépris, 1963 (France, Italy: Studio Canal, 2008, DVD). 
lives again in every one of its aspects — including its immediacy' ${ }^{65}$ This relationship to the present and creation of immediacy is perhaps where the greatest divergence between Brook's and Brecht's conceptions of theatre lies. What shocks Brecht, as Blanchot explains, is 'cette sorte de relation immédiate qui, dans le théâtre traditionnel, s'établit entre acteurs et spectateurs'. ${ }^{66}$ Arguably, Hans-Thies Lehman provides the best explanation for this reconfiguration of Brecht's practice as 'postdramatic theatre' in his eponymous book:

Alors que le théâtre épique transforme la représentation des procédés fictifs représentés et s'attache à éloigner, à distancer le spectateur pour en faire un expert, un spécialiste, une sorte de juré en politique, en revanche, dans les formes post-épiques de la narration il s'agit de mettre en valeur la présence 'personnelle' (et non plus démonstrative) du narrateur, c'est-à-dire qu'il part de l'intensité auto-référentielle de ce contact pour, dans la distance, créer de la proximité, et non pas la distanciation dans la proximité. ${ }^{67}$

The change in social habits today is more problematic for activities that rely on people being physically present at a given moment, at a given time, as part of a group. This is the case of live performance, which takes place in a specific place in a specific setting. ${ }^{68}$ Jean-Pierre Han noted in a recent article that there has been a significant increase in books bearing titles such as 'What is the point of theatre?' or 'Where is theatre going'? ${ }^{69}$ Could this be an indication that the art form's very

65. Brook, The Empty Space, p. 155.

66. Blanchot, L'Entretien infini, p. 532.

67. Hans-Thies Lehmann, Le Théâtre postdramatique, trans. by Philippe-Henri Ledru (Paris: L'Arche, 2002), p. 175

68. This is the very definition of theatre provided by Christian Biet and Christophe Triau in Qu'est-ce que le théâtre (Paris: Gallimard, 2006), p. 7.

69. Jean-Pierre Han, 'An Unlikely Scene: French Theatre in the New Liberal Economy', trans. by Dominic Glynn in Contemporary French Theatre and Performance, ed. by Clare Finburgh and Carl Lavery (Basingstoke: Palgrave Macmillan, 2011), pp. 81101, (p. 88). 
existence is threatened? It is certainly an invitation for those engaged in making theatre today to deal with the threat. One means of doing so is to move towards a hybrid form of performance by embracing the use of modern media and technologies. The work of the young director Cyril Teste with the MxM collective, such as Reset for instance, attempts to do just that. ${ }^{70}$ Another option though is to create a form of theatre that does not follow this trend, but rather, to explore an artisanal approach that emphasises the social aspect. This, I would argue, is the type of theatre that director Peter Brook created throughout his Mahabharata.

Université Paris Ouest

70. Performance dates and information about Teste's work with the collective 'Collectif MxM' are available on their website: http://www.collectifmxm.com/index. php?page=reset The appointment of the more established Philippe Quesne to the helm of the Nanterre Amandiers theatre highlights official endorsement for this approach. [Accessed 12 June 2014] 